\title{
А.В. Милежик*
}

\section{ДЕЯТЕЛЬНОСТЬ ЦЕНТРАЛЬНОЙ ШКОЛЫ ПОДГОТОВКИ КОМСОСТАВА НАРОДНОЙ МИЛИЦИИ ДВР: ОПЫТ ОРГАНИЗАЦИИ ПРОФЕССИОНАЛЬНОГО ОБРАЗОВАНИЯ НА ДАЛЬНЕМ ВОСТОКЕ РОССИИ}

\begin{abstract}
В статье рассматривается начальный этап становления профессионального образования сотрудников органов внутренних дел на территории Дальнего Востока России. На примере деятельности Центральной школы подготовки командного состава народной милиции Дальневосточной республики раскрываются особенности организации учебного и воспитательного процессов, освещается процесс формирования кадрового состава школ комсостава милиции. Автор приходит к выводу о том, что в период существования ДВР с созданием Центральной школы командного состава народной милиции были заложены основы многоуровневой профессиональной подготовки и обучения кадров в системе НКВД.
\end{abstract}

Ключевые слова: Дальневосточная республика, гражданская война, народная милиция, инструкторская школа, Министерство внутренних дел, профессиональное образование

The Central school of the people's militia officers in the Far Eastern Republic: an attempt of the organization of professional education in the Russian Far East. ALEXEY V. MILEZHIK (Vladivostok Branch of the Far Eastern Law Institute of the Ministry of Internal Affairs)

The article deals with the initial stage of the formation of law enforcement education in the Russian Far East. The author explores the structure, activities and specifics of educational process of the Central school of the people's militia officers organized in the Far Eastern Republic. The author concludes that the establishment of the school during the existence of the Far Eastern Republic laid the foundations of the multilevel professional education for the personnel of the law enforcement bodies in the region.

Keywords: Far Eastern Republic, Civil War, people's militia, instructing school, Ministry of Internal Affairs, professional education

Становление органов внутренних дел неразрывно связано с осуществлением кадровой работы по подбору, комплектованию, обучению и воспитанию личного состава. Профессиональное обучение сотрудников органов внутренних дел (полицейских, жандармов) на системной основе вплоть до революционных событий 1917 г. не осуществлялось. Изменения в государственном устройстве и управлении трансформировали правоохранительную систему. Революция сменила не только названия, заменив полицию на милицию, Министерство вну-

* МИЛЕЖИК Алексей Викторович, кандидат исторических наук, начальник кафедры гуманитарных дисциплин Владивостокского филиала Дальневосточного юридического института МВД России.

E-mail: amilezhik@rambler.ru

(C) Милежик А.B., 2018 
тренних дел Российской империи на Народный комиссариата внутренних дел РСФСР. Кардинально изменилась и система комплектования правоохранительных органов. Первостепенным для замещения должностей в органах внутренних дел молодой республики стало социальное происхождение кандидата и его лояльность к политике РКП(б) и Советской власти.

В условиях Гражданской войны и интервенции преступность в стране приобрела значительные масштабы. Для эффективного обеспечения правопорядка и общественной безопасности имеющегося уровня образования и квалификации милиционеров пролетарского происхождения было недостаточно. Так, даже командный состав рабоче-крестьянской милиции в большинстве своем имел базовое образование (80,3\% имели начальное или домашнее образование, $19,2 \%$ - среднее, и только 1,6\% высшее) [9, с. 182].

Руководство РСФСР обращало пристальное внимание на необходимость повышения уровня профессиональной подготовки милицейских кадров. Несмотря на условия военного времени, ограниченность материальных средств, нехватку высококвалифицированных кадров, в Советской республике начинает формироваться сеть учебных заведений милицейского профиля. Первые курсы и школы появились в Москве, Петрограде, Владимире уже во второй половине 1918 г., в период организационного становления милиции. Как отмечает М.А. Кожевина, по формальным признакам их можно отнести к профессиональным учебным заведениям. Образовательная деятельность осуществлялась на основе учебных планов и учебных программ, а по окончанию обучения курсанты получали свидетельства о пройденном обучении [3, с. 24].

С учетом того, что большая часть обучающихся была неграмотной или малограмотной, учебные программы включали как специальные дисциплины, так и общеобразовательные предметы из школьного курса. По сути, курсы выполняли функцию ликвидации общей и профессиональной неграмотности и малограмотности сотрудников милиции. Однако говорить о наличии системности милицейского образования в те годы не приходится.

В начале 1920-х гг. сложились необходимые предпосылки для организации системы милицейского образования: была сформирована нормативно-правовая база, регулирующая деятельность милиции, определена структура органов внутренних дел, накоплен опыт организации обучения на курсах и в школах. На основании приказа № 69 Главного управления милиции НКВД РСФСР от 17 апреля 1921 г. в республике создавалась трехуровневая система подготовки кадров милиции: на начальном уровне - 6-8-недельные курсы для первоначального обучения милиционеров и агентов уголовного розыска; на среднем - губернские милицейские школы для подготовки лиц на должности младшего командного состава со сроком обучения до 8 месяцев; на высшем - школы среднего командного состава для подготовки начальников городской и губернской милиции с 2-х летним сроком обучения [3, с. 24].

На Дальнем Востоке России формирование сети курсов и школ для сотрудников милиции осуществлялось с еще большими трудностями. Продолжавшаяся вплоть до конца 1922 г. Гражданская война, интервенция, сосуществование на территории региона нескольких идейно различных правительств и администраций - все это негативно сказывалось на деятельности правоохранительных органов.

Отметим, что специфика становления учреждений дальневосточной милиции в 1917 1920-х гг., специфика ее организационного построения, формы и методы деятельности, в том числе по направлению профессионального образования, неоднократно становились предметом исследований $[1 ; 4 ; 5 ; 6 ; 7 ; 9 ; 10 ; 11 ; 12]$.

Наибольший интерес с позиции системности вызывает опыт деятельности народной милиции Дальневосточной республики, в частности, организация профессиональной подготовки милицейских кадров. Официально Дальневосточная республика обладала суверенитетом и независимостью, но фактически руководство внешней и внутренней политикой ДВР осуществлялось ЦК РКП(б) [2, с. 404]. Поэтому многие элементы политической системы, характерные для РСФСР, присутствовали и в Дальневосточной республике. Это касалось и принципов построения правоохранительной системы. Так, народная милиция представляла собой кальку организационной структуры рабоче-крестьянской милиции РСФСР. В то же время государственно-политическая система ДВР имела свою специфику, выразившуюся, в первую очередь, в наличии демократической конституции, предполагавшей политико-идеологический плюрализм и многообразие хозяйственной системы.

В соответствии с Основным законом Дальневосточной республики, принятым в апреле 1921 г., деятельность органов внутренних дел 
регулировалась «Временным положением о народной милиции ДВР». Согласно Положению, милиция комплектовалась за счет мобилизации и на добровольной основе.

В сентябре 1921 г. был принят «Закон о милиции», в соответствии с которым определялись требования к кадровому составу народной милиции. Милиционеры должны были быть грамотными, знать основы действующего законодательства, уметь «толково и грамотно» составить протокол, а также обладать доверием со стороны населения [5, с. 41].

Нормативно закрепленные требования не всегда удавалось соблюдать. Деятельность милиции ДВР осуществлялась в условиях нестабильной военно-политической обстановки, экономического кризиса и негативного развития криминальной ситуации. Среди дальневосточников распространено было пренебрежительное отношение к любой власти и порождаемым ею правовым нормам. В ходе войны «рушилась система запретов, человек как бы освобождался от «балласта» совести и индивидуальной ответственности. Гражданская война отбросила российское общество к примитивному состоянию нравственности» [8, с. 157].

Сотрудники милиции были частью общества и в полной мере носителями имеющихся социальных болезней. Правовое сознание и морально-нравственный уровень личного состава оставляли желать лучшего. Милиционеры были социально неоднородны, в основном малограмотны, со слабыми представлениями о своих профессиональных обязанностях. Как отмечалось в отчете руководителя милиции республики, главного правительственного инспектора Н.И. Колесниченко, штаты были заполнены участниками партизанского движения, людьми благонадежными, но «без всяких знаний и опыта в милицейском деле» [5, с. 42].

Моральный облик милиционера был далек от идеала. Проводившиеся проверки подразделений милиции выявляли факты нарушения сотрудниками служебной дисциплины, превышения должностных полномочий, а также совершения ими уголовных преступлений [7, c. 121]. Отмечался низкий уровень сознательности и мотивации милиционеров к службе.

По результатам проверок проводились регулярные чистки кадров, перемещения милиционеров в другие подразделения. Для поднятия уровня политической сознательности и оздоровления морального климата коллективов активно привлекались комсомольские и партий- ные кадры. Несмотря на все усилия, проблема повышения профессиональной грамотности и сознательности милиционеров долгое время оставалась нерешенной.

Сложившееся в милиции положение вызывало беспокойство у руководства органов внутренних дел республики. Начальник Читинской городской милиции В. Бородулин в рапорте министру внутренних дел республики охарактеризовал милицию как учреждение, требующее «всесторонних знаний и подготовку и более или менее высокое умственное и нравственное развитие сотрудников» (Государственный архив Забайкальского края, далее - ГАЗК. Ф. Р-402. Оп. 1. Д. 55. Л. 518).

В январе 1921 г. на заседании коммунистической фракции Народного собрания ДВР впервые был поставлен вопрос о создании сети образовательных заведений по профессиональной подготовке кадров для милиции. В первой половине 1921 г. в Верхнеудинске, Благовещенске и Чите учреждаются губернские 4-х месячные курсы подготовки милиционеров [4, с. 12].

Главным управлением милиции была разработана учебная программа подготовки милиционеров. Согласно программе, курсанты изучали внутреннюю и наружную службу милиционера-надзирателя, военную подготовку, основы уголовного и гражданского права и процесса. К концу 1921 г. предполагалось обучить свыше 300 человек [5, с. 44]. Опыт работы милицейских курсов в 1921 г. был оценен как положительный (ГАЗК. Ф. Р-402. ОП. 1. Д. 55. Л. 545). Милиционеры, окончившие курсы, в служебной деятельности отличались «дисциплинированностью, знанием дела, выдержанностью и благонадежностью, как с политической стороны, так и со стороны нравственных качеств» (ГАЗК. Ф. Р-402. ОП. 1. Д. 55. Л. 545).

Следует отметить, что учрежденные курсы осуществляли подготовку рядового состава милиции. Между тем, назрела необходимость в профессиональной подготовке командного состава народной милиции (ГАЗК. Ф. Р-402. Оп. 1. Д. 55. Л. 325). Для решения данного вопроса из Верхнеудинска в Читу был откомандирован начальник милицейских курсов Прибайкальской области В.Н. Добронравов, обладавший достаточным опытом в организации работы курсов в Прибайкалье.

По инициативе В.Н. Добронравова 26 июля 1921 г. были созданы Центральные милицейские инструкторские курсы (ГАЗК. Ф. Р-402. ОП. 1. Д. 42. Л. 1). Учебное заведение республиканского 


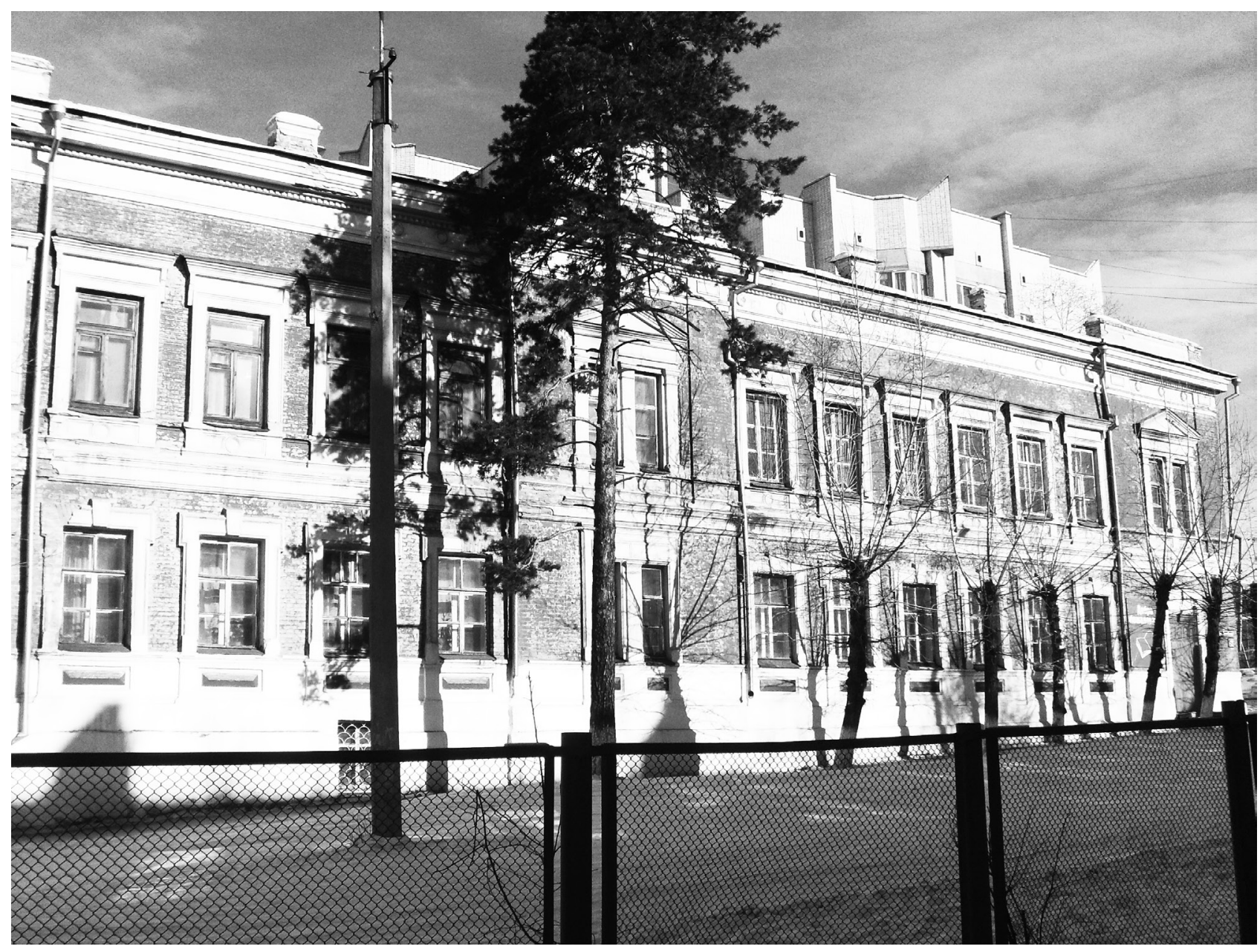

Puc. 1. Здание, в котором в 1921-1924 гг. размещалась Центральная школа подготовки комсостава народной милиции ДВР. Фото автора

значения было размещено на втором этаже здания епархиального училища, на углу улиц Троицкосавской и Мариинской (в настоящее время - ул. Балябина, 48). Здание сохранилось до настоящего времени, находится в хорошем состоянии и продолжает служить делу образования. В нем располагается средняя общеобразовательная школа № 32 г. Читы (Рис. 1).

Начальником курсов был назначен Абрам Иосифович Абрамов, человек интересной судьбы. Профессиональный революционер, эсер-террорист (партийная кличка «Барс»), был приговорен к смертной казни, замененной пожизненной каторгой на Сахалине, откуда бежал в Японию, затем - в Австралию и Францию. Участвовал в Первой мировой войне. После свержения монархии вернулся в Россию и в 1918 г. вступил в ряды партии большевиков. До назначения на должность начальника курсов А.И. Абрамов служил командиром Красной армии, затем Народно-революционной армии ДВР [5, с. 44].

Значение курсов для подготовки командного состава милиции подтолкнуло руководство
Главного управления народной милиции к их реорганизации. 6 августа 1921 г. курсы были преобразованы в Центральную милицейскую инструкторскую школу с увеличением срока обучения до 6 месяцев (ГАЗК. Ф. Р-402. Оп. 1. Д. 36. Л. 39). На август 1921 г. личный состав школы насчитывал 67 человек (без гражданских служащих), в том числе 56 курсантов.

А.И. Абрамову пришлось приложить значительные усилия для налаживания образовательного процесса в школе. В первую очередь необходимо было решить ряд вопросов материально-технического обеспечения: обустройство учебных аудиторий и жилых помещений, снабжение продовольствием и обмундированием, учебными пособиями, бумагой и письменными принадлежностями. Недостатки снабжения наглядно проявлялись во внешнем виде курсантов. В октябре 1921 г. за «разнообразно одетую» роту курсантов начальником народной милиции ДВР начальнику школы был объявлен строгий выговор (ГАЗК. Ф. Р-402. Оп. 1. Д. 36. Л. 55$)$. 
Еще более важными, чем вопросы снабжения, были вопросы содержания обучения и комплектования преподавательского состава. А.И. Абрамову удалось сформировать коллектив опытных педагогов: В.Г. Бородулин, П.С. Губанов, Н.Ф. Сущевич, Н.А. Холодов (ГАЗК. Ф. Р-402. Оп. 1. Д. 64. Л. 42). Обучение основывалось на лекционно-репетиционном методе, объединяющем теоретическую и практическую подготовку [4, с. 15]. Курсанты изучали различные учебные дисциплины - от арифметики и русского языка до уголовного, административного и конституционного права. Кроме того, осуществлялась военная и строевая подготовка.

Как и во всей дальневосточной милиции пристального внимания требовали вопросы воспитания и укрепления дисциплины личного состава. Руководству народной милицией ДВР и непосредственно начальнику школы для наведения порядка приходилось принимать достаточно жесткие меры воздействия, не взирая на должности и партийную принадлежность. Приказом начальника народной милиции ДВР № 34 от 10 августа 1921 г. комсоставу школы в лице командиров Басова, Шайкина и Бурунова были объявлены выговоры за беспорядок и неприличное поведение в общежитии (ГАЗК. Ф. Р-402. Оп. 1. Д. 36. Л. 40). Показательна выдержка из приказа по школе № 8 от 6 августа 1921 г.: «3. Арест на 1 сутки за несвоевременную явку на поверку комвзвода Бурунова... 6. Полуротного командира Алексеева за манкирование службой арест на 7 суток... 8. Строгий выговор комроты Добронравову за неправильную подачу рапортов. 9. Комвзода Шайкину строгий выговор за подачу жалобы не по команде. 10. Весь комсостав курсов и курсантов предупреждаю, что за обращение не по команде буду подвергать дисциплинарному взысканию» (ГАЗК. Ф. Р-402. Оп. 1. Д. 64. Л. 34).

Понимая, что дисциплина основывается на планомерной воспитательной работе, руководство уделяло значительное внимание развитию духовно-нравственных качеств личности курсантов. В школе была организована художественная самодеятельность, участники которой устраивали для коллектива и гостей школы спектакли и концерты (ГАЗК. Ф. Р-402. Оп. 1. Д. 42. Л. 24).

Меры, проведенные руководством и педагогическим коллективом, позволили наладить в школе плодотворную работу по подготовке необходимых республике милицейских кадров. 12 ноября 1921 г. экзаменационная комиссия произвела письменные и устные испытания 62 курсантам. Курс был закончен успешно. На командные должности по первому разряду рекомендовано было 14 человек, по второму разряду - 12, на низшие должности по первому разряду - 24, по второму - 12 человек (ГАЗК. Ф. Р-402. Оп. 2. Д. 12. Л. 88).

После выпуска А.И. Абрамов получил благодарность от руководства народной милиции ДВР, по собственному желанию был уволен с должности начальника школы, а затем переведен в Москву (ГАЗК. Ф. Р-402. Оп. 2. Д. 40. Л. 6). Как и у многих руководителей той поры, судьба А.И. Абрамова сложилась трагически. В 1926 г., в период чисток, за приверженность идеологии террора он был исключен из партийных рядов, а в 1938 г. арестован и расстрелян.

Второй набор в школу осуществлял уже новый начальник - Александр Васильевич Нахлупин. А.В. Нахлупин имел педагогическое образование и большой опыт административной работы в качестве заведующего учебной частью 1-ой объединенной военной школы им. ВЦИК РСФСР (ГАЗК. Ф. Р-402. Оп. 2. Д. 29. Л. 16). Учебные занятия у нового набора начались не 5 декабря 1921 г., как планировалось, а почти на 2 месяца позже. Главной причиной срыва начала учебного процесса стал значительный недокомплект переменного состава (72 курсанта против 117 по штату). Кандидаты поступали, но в силу несоответствия требованиям откомандировывались обратно. Докладывая руководству милиции республики, А.В. Нахлупин указывал, что «вместо надзирателей и старших агентов уголовного розыска, здоровых, грамотных и благонадежных в политическом отношении... с мест оказались присланными милиционеры, иногда совершенно малограмотные, и с физическими недостатками, что конечно не может не отразиться на ходе теоретических и строевых занятий» (ГАЗК. Ф. Р-402. Оп. 1. Д. 101. Л. 113). По мнению начальника школы, руководством милиции на местах «не вполне уяснены задачи и цели, возложенные на школу с одной стороны, и с другой стороны, видимо, минимальные штаты милиции не представили возможности выполнить, как разверстку полностью, так и отправить по ней людей, удовлетворяющим требованиям школы» (ГАЗК. Ф. Р-402. Оп. 1. Д. 101. Л. 113). Критичным было несоответствие уровня образования кандидатов требованиям школы командного состава. Абсолютное большинство курсантов (50 из 72 человек) имели только домашнее или начальное образование, 
лишь двое имели среднее образование (ГАЗК. Ф. Р-402. Оп. 1. Д. 101. Л. 113).

Не лучше обстояло дело с формированием постоянного состава школы. Командиры взводов, за исключением командира кавалерийского взвода, окончившего кавалерийские командные курсы, не имели соответствующего военного образования и опыта воспитательной работы. Между тем, задачи школы состояли в том, чтобы «подготовить дисциплинированных, обученных военному и милицейскому делу и воспитанных политически в духе уважения к законам республики» руководящих работников народной милиции. Поэтому вопрос комплектования командного состава школы руководителями и ближайшими воспитателями курсантов являлся одним из основных (ГАЗК. Ф. Р-402. ОП. 1. Д. 101. Л. 113).

По мнению А.В. Нахлупина, главным препятствием для набора младших командиров, соответствующих требованиям, «является недостаточная оплата труда». Жалование командира составляла 50-60 руб. золотом в месяц, причем половину необходимо было сдавать на столовые расходы.

К организации образовательного процесса А.В. Нахлупин подошел с должным профессионализмом. Руководство учебной часть осуществлялось начальником школы и педагогическим советом, в который входили не только преподаватели, но представители от курсантов. Проявлялся неподдельный интерес к проблемам курсантов. Инициатива курсантов по улучшению преподавания учебных предметов активно поддерживалась администрацией школы. Начальник школы неоднократно посещал учебные занятия с целью оценки качества преподавания. А.В. Нахлупин отмечал необходимость излагать учебные дисциплины «картинно, применяясь к общему уровню развития курсантов, с привлечением всего класса к работе» (ГАЗК. Ф. Р-402. ОП. 1. Д. 101. Л. 114).

$\mathrm{C}$ целью повышения образовательного уровня курсантов учебная программа предполагала изучение уголовного права и процесса, конституционного и административного права, милицейской службы, воинских уставов, судебной медицины, политграмоты, русского языка, математики, естествознания, географии, тактики и топографии. Моральный облик курсантов формировался посредством работы культурно-просветительной комиссии, которая организовала изучения азбуки коммунизма, театральную, хоровую и спортивную секции.
Несмотря на проводимую администрацией, преподавателями и активом школы работу продолжали сохранять актуальность вопросы поддержания дисциплины. Начальник школы констатировал, что «постановка дисциплины в школе на соответствующую высоту и усвоение курсантами необходимости ее потребует еще усиленной работы со стороны администрации школы, так как в большинстве - курсанты или из партизан, с тенденциями к партизанщине, или видевшие разложение старой армии при керенщине и не служившие с того времени в армии, почему, в первое время, всякое требование, предъявляемое администрацией к курсантам, встречалось с глухим протестом или открыто высказывалось командирам взводов, что это старорежимная царская дисциплина» (ГАЗК. Ф. Р-402. Оп. 1. Д. 101. Л. 116).

К нарушителям дисциплины применялись все меры воздействия - от внушений до арестов и увольнений. Были отчислены курсанты Азарий Редров и Виталий Терский за систематические нарушения правил школы, неблаговидное поведение и полное нежелание подчиняться распоряжениям комсостава (ГАЗК. Ф. Р-402. Оп. 1. Д. 101. Л. 107 - 108). Увольнялись со службы и по собственному желанию. Курсант Федор Калицкий объяснял свое желание уволиться из милиции так: «...Требуются люди здоровые, с крепкими нервами без суетливости, а так как у меня имеется болезнь неврастение и ревматизм, что в подтверждения прилагаю удостоверение врача. И я с моим здоровьем для милиции не гожусь, так как малейшая ненормальность вздергивает и я вскипаю до невозможности, что нет сил себя сдержать, а в милиции именно требуется хладнокровие, выдержанность, крепкие нервы и я с моим здоровьем не оправдаю тех затрат которые будут затрачены на меня государством. Я не поправлю своего здоровья в милиции, а хуже еще разрушится и пользы не будет не для меня и для государства, а к этому у меня имеется склонность совершенно к другим отраслям: к летературе, политике и хозяйству. А поэтому прошу откомандировать меня из школы как человека не здорового и не способного для милицейской работы» (ГАЗК. Ф. Р-402. Оп. 1. Д. 101. Л. 444).

В условиях военного времени, курсанты отвлекались от учебного процесса для участия в операциях по ликвидации различных бандформирований. Летом 1922 г. личный состав школы во главе с командиром роты П.Г. Пиотровским участвовал в ликвидации банды вахмистра Гордеева. В боях с бандитами погиб помощник на- 
чальника школы Николай Васильевич Лебедев [4, с. 17].

В июле 1922 г. в Центральной милицейской инструкторской школе состоялся второй выпуск. Выпускники школы характеризовались непосредственными и вышестоящими начальниками в целом положительно. Отмечалась их хорошая теоретическая и практическая подготовка, дисциплинированность и исполнительность, «сознательно-революционный» настрой (ГАЗК. Ф. Р-402. ОП. 2. Д. 29. Л. 9).

Заслуги личного состава школы в нелегком труде по воспитанию кадров для милиции были отмечены руководством Дальневосточной республики. Коллектив Центральной милицейской школы был награжден знаменем и грамотой Министерства внутренних дел ДВР (Рис. 2). Отмечалось, что школа является «мощным рычагом оздоровления и создания революционного и сознательного кадра начальников народной милиции, высоко и честно несущих знамя борьбы за право, порядок, законность и укрепление власти трудящихся» (ГАЗК. Ф. Р-15. Оп. 1. Д. 93. Л. 2).

После второго выпуска А.В. Нахлупин был переведен на должность правительственного инспектора милиции Забайкальской области. Центральную школу комсостава народной милиции возглавил Николай Васильевича Главацкий (Рис. 3). Его карьера началась с юнкерского училища, которое он окончил в чине подпоручика императорской армии. Всесторонне образованный, человек высокой культуры, Николай Васильевич вскоре окончил разведывательный факультет Николаевской академии Генерального штаба и нес службу в разведывательном ведомстве Генштаба, дослужившись до полковника.

После революции 1917 г. Н.В. Главацкий воевал в армии Колчака, затем перешел на сторону красных, служил в штабе Народно-революционной армии Дальневосточной республики. В 1922 г. был назначен в Центральную милицейскую школу комсостава Рабоче-крестьянской милиции Дальневосточной области. Кадровый военный, Н.В. Главацкий имел опыт руководства военным училищем в Иркутске. Николай Васильевич знал несколько иностранных языков, обладал широким кругозором и солидным педагогическим опытом. Он преподавал тактику и топографию в Одесском и Иркутском военных училищах.

Третий набор курсантов осуществлялся с не меньшими трудностями. Запросы на кандидатов для обучения в инструкторской школе направлялись не только в подразделения милиции, но и в Дальбюро РКП(б), Военный совет НРА, Дальневосточный совет профсоюзов (ГАЗК. Ф. Р-402. Оп. 1. Д. 101. Л. 469, 475, 478). В школу прибыл только 81 кандидат. Кандидаты должны были отвечать требованиям по физическому здоровью, иметь образование не ниже начального училища, быть не моложе 18 лет и являться гражданами Дальневосточной республики. В случае сомнений в подлинности документов об образовании поступающие сдавали экзамен по русскому языку и математике. Важное значение имела политическая и нравственная благонадежность кандидата, которая подтверждалась поручительством правительственных учреждений, политических и гражданских организаций Дальневосточной республики (ГАЗК. Ф. Р-402. Оп. 1. Д. 101. Л. 302).

Часть кандидатов не выдержала проверочных испытаний, другая была откомандирована по физической непригодности, за дисциплинарные проступки и по собственному желанию. В итоге, к учебным занятиям 18 сентября 1922 г. приступило 62 курсанта.

Из поступивших в школу большая часть имела 2-х классное или домашнее образование (38,7\% и 29\% соответственно). Только 6 курсантов $(10,4 \%)$ окончили вторую ступень школы. Повышенные требования к политической благонадежности сказались на увеличении среди курсантов количества членов и кандидатов РКП(б) - 14 человек (почти 22\%) (ГАЗК. Ф. Р-402. Оп. 1. Д. 101. Л. 546).

Под руководством Н.В. Главацкого коллектив школы работал как хорошо отлаженный механизм. Занятия проводились в соответствии с расписанием с утра и до обеда. Нехватка учебников и пособий восполнялась размножением конспектов лекций на гектографе. В отчете начальника школы Н.В. Главацкого отмечалось: «...По общему заявлению преподавателей курсанты проявляют значительный интерес к читаемому курсу, относятся к лекциям со вниманием и любознательностью... Классная дисциплина нормальная, случаев нарушения еще не было... По единогласному признанию преподавателей введенная лекционно-репетиционная система преподавания является наилучшей для данной школы» (ГАЗК. Ф. Р-402. Оп. 1. Д. 101. Л. 547).

Окончившие шестимесячный курс имели право на замещение командных должностей в народной милиции ДВР по усмотрению Главного правительственного инспектора. В то же время, каждый выпускник обязан был прослужить в органах внутренних дел не менее одного года. 


\section{1/5. \\ Jpasroma.

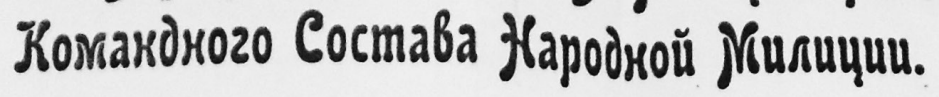

Jrusucmepcmbo Вкутрекsuх Den D. B. P.- Цектралькой Ukколе

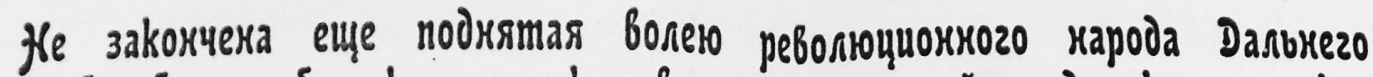

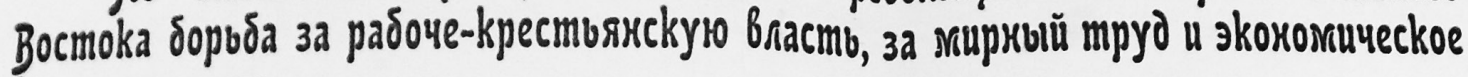

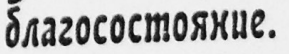

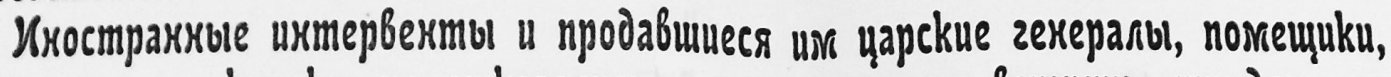

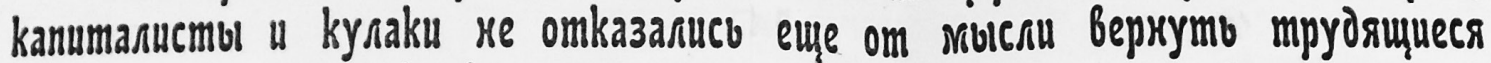

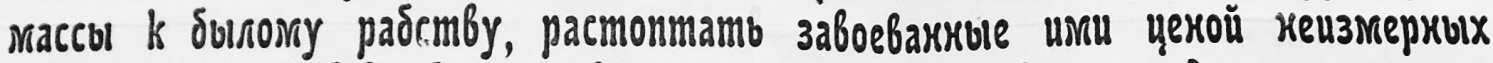

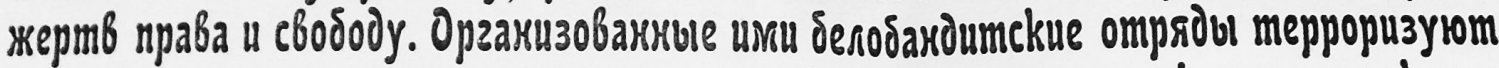

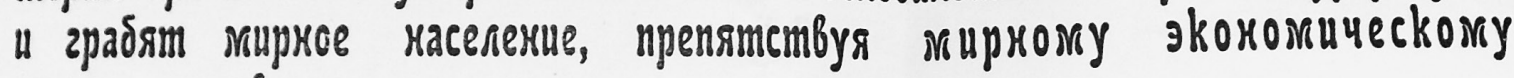
cmpoumesibemby.

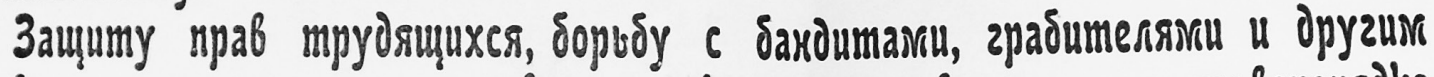

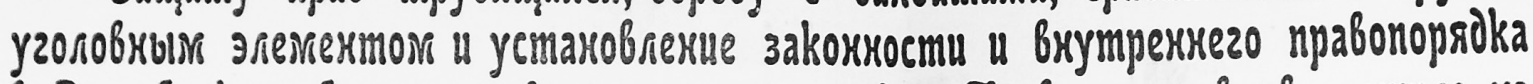

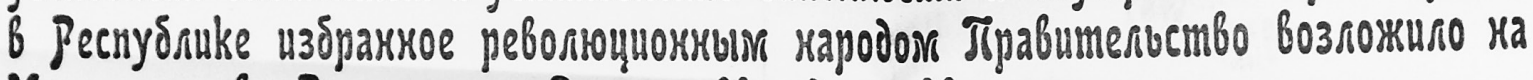

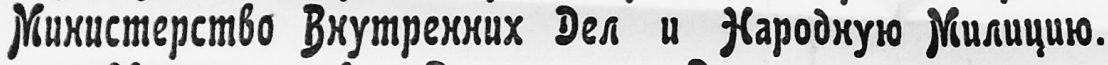

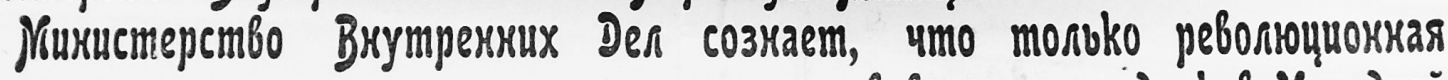

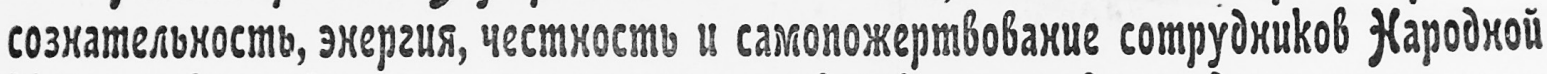

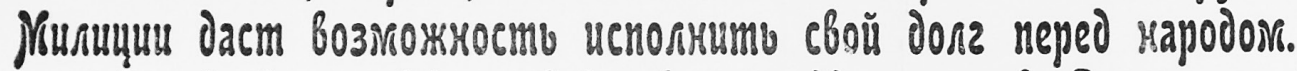

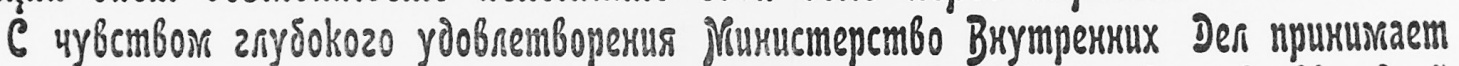

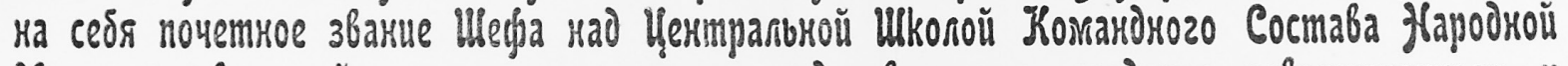

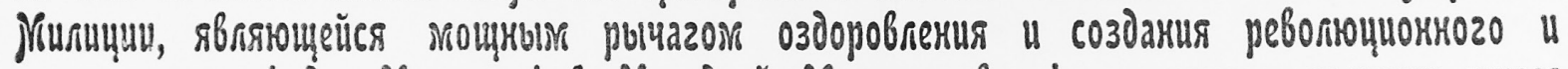

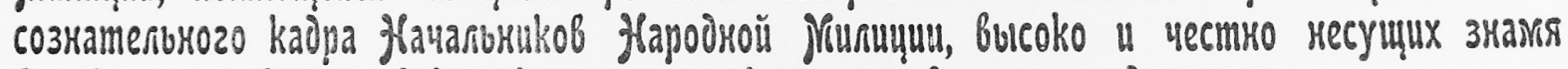

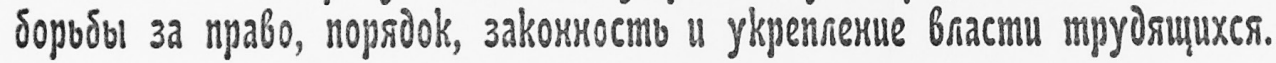

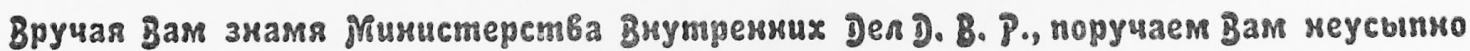

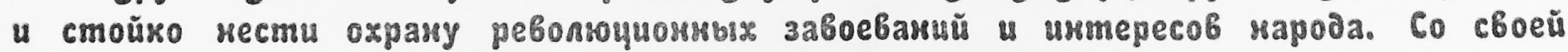

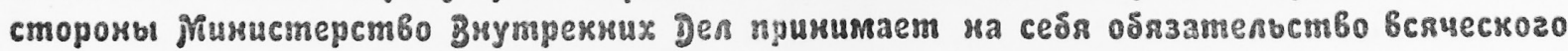

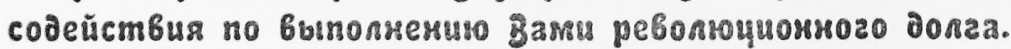

I. Yuma, 1-20 พая 1922.2.

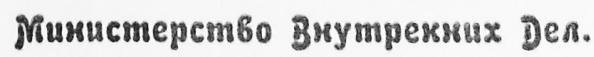

Рис. 2. Грамота Министерства внутренних дел ДВР. Источник: ГАЗК. Ф. Р-15. Оп. 1. Д. 93. Л. 2 


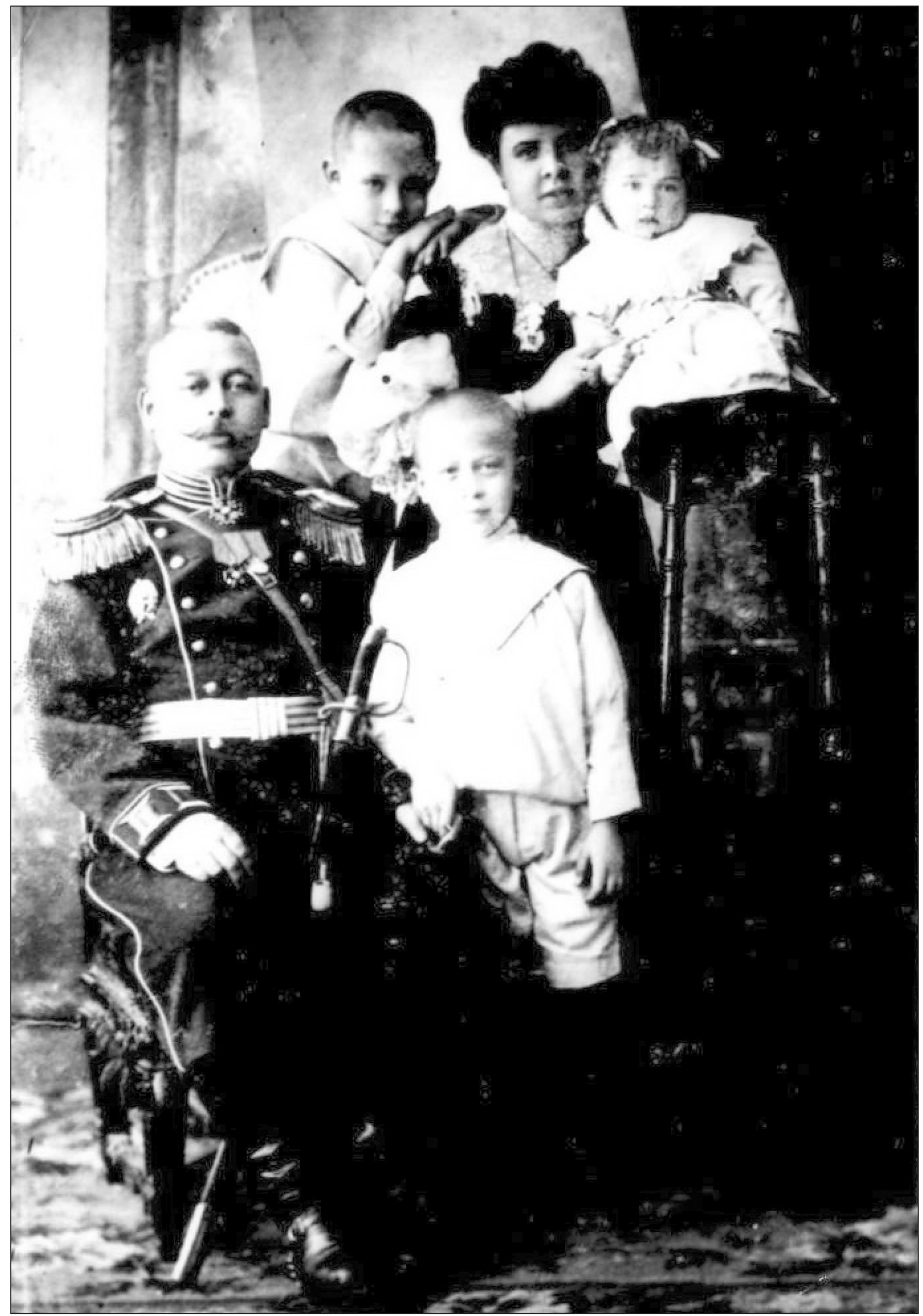

Рuc. 3. Н.В. Главацкий с семьей. 1908 г. Из личного архива семьи Главацких 
В ноябре 1922 г. Гражданская война на Дальнем Востоке завершилась, и Дальневосточная республика вошла в состав РСФСР. Народная милиция ДВР стала составной частью рабоче-крестьянской милиции. 29 ноября 1922 г. Центральная школа подготовки комсостава народной милиции ДВР получила наименование Центральная милицейская школа комсостава РКМ Дальневосточной области РСФСР. Благодаря самоотверженной, подвижнической деятельности руководства и коллектива школы были заложены основы многоуровневой профессиональной подготовки и обучения кадров в системе НКВД. Ряды дальневосточной милиции пополнились настоящими профессионалами, обладавшими достаточными знаниями и навыками, чтобы эффективно противодействовать преступности.

\section{СПИСОК ЛИТЕРАТУРЫ}

1. Бакшутов С.Н., Орнацкая Т.А., Шабельникова Н.А. Дальневосточная милицейская школа в государственной системе профессионального образования (1918-2011 гг.). Владивосток, 2017.

2. История Дальнего Востока России. Т. 3. Кн. 1: Дальний Восток России в период революций 1917 г. и гражданской войны. Владивосток: Дальнаука, 2003.

3. Кожевина М.А. Милицейское образование в Советской России: организация и правовое регулирование: автореф. дис. ... д-ра юр. наук. M., 2005.

4. Кутушев В.Г. Дальневосточный юридический институт МВД России: история и современность. Хабаровск: ДВЮИ МВД РФ, 1998.

5. Орнацкая Т.А. Народная милиция Дальневосточной республики: комплектование и подготовка кадров // Каспийский регион: политика, экономика, культура. 2016. № 2. С. 39-47.

6. Орнацкая Т.А., Головин С.А. Флагман подготовки милицейских кадров на Дальнем Востоке (об обучении юристов в начале 1920-х гг.) // Гуманитарные науки и образование. 2018. Т. 9. № 1. С. 148-153.

7. Орнацкая Т.А. К вопросу о моральных устоях дальневосточных милиционеров в 19201922 гг. // Чтения памяти профессора А.А. Сидоренко: материалы регион. заоч. науч.-практ. конф. Благовещенск, 2016. С. 119-124.

8. Светачев М.И. Конференция историков: новые поиски // Вестник ДВО РАН. 1992. № 5-6. С. 157.

9. Шабельникова Н.А., Бакшутов С.Н. Формирование системы профессионального обучения кадров милиции на Дальнем Востоке
России в 1920-е гг. // Теория и практика общественного развития. 2015. № 21. С. 182-185.

10. Шабельникова Н.А. Исторический опыт формирования Дальневосточной милиции в 1917-1922 гг. // Вестник Дальневосточного юридического института МВД России. 2014. № 2. С. 71-82.

11. Шабельникова Н.А. Милиция в борьбе с преступностью на Дальнем Востоке России (1922-1930 гг.). Владивосток: Дальнаука, 2002.

12. Энциклопедия славных дел: Дальневосточному юридическому институту МВД России - 95 лет / под ред. А.А. Андреева. Хабаровск, 2016.

\section{REFERENCES}

1. Bakshutov, S.N., Ornatskaya, T.A. and Shabel'nikova, N.A., 2017. Dal'nevostochnaya militseyskaya shkola $\mathrm{v}$ gosudarstvennoy sisteme professional'nogo obrazovaniya (1918-2011 gg.) [Far Eastern Militia School in the state system of professional education, 1918-2011]. Vladivostok. (in Russ.)

2. Istoriya Dal'nego Vostoka Rossii. T. 3. Kn. 1. Dal'nii Vostok Rossii v period revolyutsii 1917 goda i grazhdanskoi voiny [History of the Russian Far East. Vol. 3. Book 1. Russian Far East during the Revolutions of 1917 and Civil war]. Vladivostok, 2003. (in Russ.)

3. Kozhevina, M.A., 2005. Militseyskoe obrazovanie v Sovetskoy Rossii: organizatsiya i pravovoe regulirovanie [Militia education in Soviet Russia: organization and legal regulation], avtoreferat dissertatsii doktora yuridicheskikh nauk. Moskva. (in Russ.)

4. Kutushev, V.G., 1998. Dal'nevostochnyy yuridicheskiy institut MVD Rossii: istoriya $i$ sovremennost' [Far Eastern Law Institute of the Ministry of Internal Affairs of Russia: history and modern times]. Khabarovsk: DVYuI MVD RF. (in Russ.)

5. Ornatskaya, T.A., 2016. Narodnaya militsiya Dal'nevostochnoy respubliki: komplektovanie i podgotovka kadrov [The People's Militia of the Far Eastern Republic: recruitment and training], Kaspiyskiy region: politika, ekonomika, kul'tura, no. 2, pp. 39-47. (in Russ.)

6. Ornatskaya, T.A. and Golovin, S.A., 2018. Flagman podgotovki militseyskikh kadrov na Dal'nem Vostoke (ob obuchenii yuristov v nachale 1920-kh gg.) [The leader in the field of police education in the Soviet Far East (on the training of lawyers in the early 1920s)], Gumanitarnye nauki i obrazovanie, Vol. 9, no. 1, pp. 148-153. (in Russ.) 
7. Ornatskaya, T.A., 2016. K voprosu o moral'nykh ustoyakh dal'nevostochnykh militsionerov v 1920-1922 gg. [On the issue of the moral foundations of the Far Eastern militiamen in 1920-1922]. In: Chteniya pamyati professora A.A. Sidorenko: materialy region. zaoch. nauch.-prakt. konf. Blagoveshchensk, pp. 119-124. (in Russ.)

8. Svetachev, M.I., 1992. Konferentsiya istorikov: novye poiski [History conference: a new search], Vestnik DVO RAN, no. 5-6, p. 157. (in Russ.)

9. Shabel'nikova, N.A. and Bakshutov, S.N., 2015. Formirovanie sistemy professional'nogo obucheniya kadrov militsii na Dal'nem Vostoke Rossii v 1920-e gg. [Formation of the system of militia professional training in the Russian Far East in the 1920s.], Teoriya i praktika obshchestvennogo razvitiya, no. 21, pp. 182-185. (in Russ.)
10. Shabel'nikova, N.A., 2014. Istoricheskiy opyt formirovaniya Dal'nevostochnoy militsii v 1917-1922 gg. [History of the formation of the Far Eastern militia in 1917-1922], Vestnik Dal'nevostochnogo yuridicheskogo instituta MVD Rossii, no. 2, pp. 71-82. (in Russ.)

11. Shabel'nikova, N.A., 2002. Militsiya v bor'be s prestupnost'yu na Dal'nem Vostoke Rossii (1922-1930 gg.) [Police in the fight against crime in the Russian Far East, 1922-1930]. Vladivostok: Dal'nauka. (in Russ.)

12. Andreev, A.A. ed., 2016. Entsiklopediya slavnykh del: Dal'nevostochnomu yuridicheskomu institutu MVD Rossii - 95 let [Encyclopedia of glorious deeds: the 95th anniversary of the Far Eastern Law Institute of the Ministry of Internal Affairs of Russia]. Khabarovsk. (in Russ.)

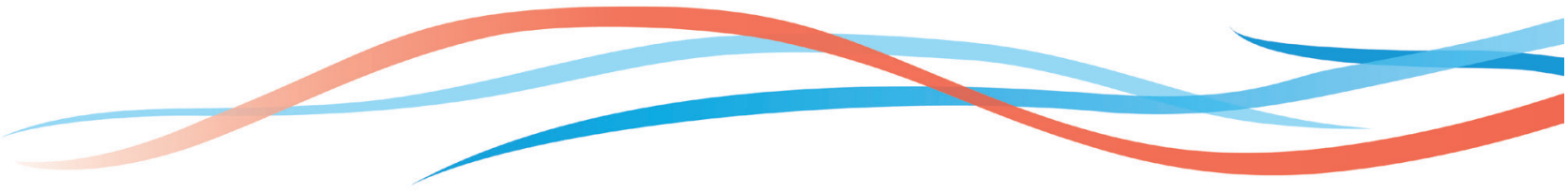

